belonged to the Parasitica and the ants. Of the Diptera the most abundant families represented were the Chloropida with 2,227 specimens and the Chironomidæ with 701 examples. Culicidæ were represented by 111 specimens belonging to seven genera.

Among apterous forms, 1,461 spiders were captured, one example occurring at $15,000 \mathrm{ft}$. A single example of Pulex irritans at $200 \mathrm{ft}$. is recorded. Numerous Apterygota are mentioned, besides wingless Hymenoptera, etc., and larvæ.

Among the various factors governing the distribution of insects in the upper air the size, weight and buoyancy of individual forms are discussed together with the influence of temperature, dewpoint, barometric pressure, wind direction and velocity, convection, light intensity, etc. Of these, and other factors, temperature is regarded as the most important agency regulating the numbers of insects to be found in the air at any given time.

With the great number of acroplanes now in regular use in the world, numerous ways are offered for insects to find shelter in these vehicles and so become carried from one territory to another. New means for the dispersal of dangerous insect pests are thus afforded. Air currents are also believed to be an important accessory factor in the distribution of the destructive pink bollworm in the United States. During the five years of flying to collect insects, many kinds of these creatures were found either in the cockpit, fuselage or cabin of the planes used, but no special collections were made.

\title{
OBITUARIES
}

General the Hon. C. G. Bruce, C.B.

$\mathrm{B}$ RIGADIER-GENERAL THE HON. C. G. BRUCE died on July 12 at the age of seventythree years.

Charles Granville Bruce, born in 1866, was a son of the first Lord Aberdare. Probably no man since the time of the Schlagintweits had a wider knowledge of the Himalaya than Bruce. No one ever had so intimate a knowledge of so many of its peoples. Bruce's climbing experience extended from the Safed Koh to Sikhim. He was with Conway in his notable expedition to the Karakorum, and with Mummery and Collie in the first attempt on Nanga Parbat. The snows of Khagan and Kulu were his happy hunting grounds. In 1907, the jubilee year of the Alpine Club, he nearly arranged the first exploration of Nount Everest; but at the last moment the plan was vetoed in London by John Morley, who feared Russian suspicion. Again in 1910 he got leave from the late Maharaja to explore Everest from the Nepalese side; but at the last moment this had to be given up for fear of arousing religious hostility.

By profession a soldier, Bruce was an acknowledged master in the difficult technique of fighting on the North-West Frontier. His influence with his own Gurkhas was remarkable, and his greatest contribution to mountaineering came through his wide knowledge of the tribes of the Himalaya. He was the first to use trained Gurkhas for serious mountain work. He started the Baltis of Kashmir and the Bhotias of Garhwal on the upward path, a lead which Kellas ably followed. But his great discovery was the value of the Sherpa, a Tibetan tribe long settled in Nepal. These, with their purer Tibetan cousins, have been the mainstay of every Himalayan expedition of recent years. The cause of his success was his sympathy with and knowledge of the languages and habits of these very varied peoples.

In 1923 Bruce was elected president of the Alpine Club. In 1915 he was awarded the Gill Memorial Prize and in 1925 the Founder's Medal of the Royal Geographical Society. But it was the adventure, not scientific interests, which absorbed him during his climbing holidays and longer oxpeditions. Of the latter, the Everest expedition of 1922 stands out. He made an ideal leader. Yet it is as a companion, the perfect ono, that I most remember him, especially with Arnold Mrumm and myself in Garhwal in 1907. He was the most invariably considerate, and pleasant, and uncomplaining companion it is possible to imagine. Not even the injured knee which deprived him of climbing Trisul with his devoted Subadar Khàrbir Burathoki drew one word of disappointment or complaint from him. Bruce's name became a household word : but only his friends knew his real worth. T. G. LongstafF.

\section{Prof. Archibald Young}

Prof. Archibald Young, who died in Glasgow on July 24 at the age of sixty-five years, had held the regius professorship of surgery in the University of Glasgow since 1924, when he succeeded Sir Williarn Macewen: He had come under the influence of his predecessor, and this partly accounted for his leaning towards the surgery of the nervous system, to which he had regularly contributed since his service in the South African War. MIoreover, this choice of speciality was natural in one whose clinical inclinations were coloured by the minutest examinations of clinical cases.

Prof. Young was at his best in dealing with 